\title{
STUDY OF ZOOPLANKTON COMPOSITION, DIVERSITY AND ABUNDANCE FROM DIFFERENT TYPES OF WATER SOURCES
}

\author{
KumariSushma Saroj ${ }^{1}$ and Sanjeev Kumar Vidyarthi ${ }^{2}$ \\ ${ }^{1}$ Department of Zoology, Dr. L.K.V.D. College, Tajpur, Samastipur \\ ${ }^{2}$ Department of Botany2, Dr. L.K.V.D. College, Tajpur, Samastipur, \\ Lalit Narayan MithilaUnivesity, Darbhanga, Bihar, India \\ https://doi.org/10.35410/IJAEB.2020.5565
}

\begin{abstract}
The present studies were investigated for a period of one year sampling every month. The zooplankton comprised of 36 species belonging to three group viz., Rotifera, Cladocera and Copepoda. The relative abundance of Rotifera was high in two different studied areas (site 2 and site 3) $43.08 \%$ and $38.60 \%$ respectively. The zooplankton species richness indices were high in water sources of site 2 than the other observed study areas. The detailed aspect of composition, abundance and diversity trend of zooplankton is investigated herein. The findings of the present study provide useful knowledge on the spatial organization of zooplankton diversity in different types of water sources as well as can be used as management strategies to protect the aquatic biodiversity in the agricultural area.
\end{abstract}

Keywords: Zooplankton, Rotifera, Cladocera, Copepoda.

\section{INTRODUCTION}

Zooplankton are microscopic animals that act as primary and secondary links in the food webs of all aquatic ecosystems. They feed on phytoplankton which directly provide food source for larval vertebrates and invertebrates as well as related to the growth of juvenile and larger fish. They are also important component in the transfer of energy from primary producers of phytoplankton to higher trophic levels suchas fish [1]. Regarding the habitat, zooplankton are cosmopolitan fauna and inhabit all freshwater bodies of the world [2]. These communities are also sensitive to various substances in water such as nutrient enrichment and pollutants. Thus, they have often been used as indicators to assess the condition and change of the freshwater environment particularly in the northern hemisphere [3].

Therefore, the present study aimed at evaluating the taxonomic composition, abundance and diversity of zooplankton over a period of one year in three different sites to determine the diversity of zooplankton among the water sources.

\section{MATERIALS AND METHODS}

The distribution of zooplankton was investigated from three different sites of Samastipur, Bihar from June 2019 to May 2020. The three different sites for Qualitative and quantitative 
zooplankton samples were collected by filtering 50 Liter water from the different study sites at monthly intervals from the surface waters with the help of plankton net. Collected specimens were preserved in 5\% formalin for quantitative and qualitative examination. Zooplankton enumeration were done by introducing $1 \mathrm{ml}$ of the preserved sample into Sedgwick-Rafter counting chamber for detailed taxonomic identification with the help of a stereoscopic microscope having different magnifications (X 10 initially, followed X 40).Zooplankton identification was done to generic level according to various authors [4, 5, 6, 7, 8]. Various statistical analyses were done in accordance with the procedures Ludwig et.al. [9].

\section{RESULTS AND DISCUSSIONS}

The zooplankton fauna of the investigated areas comprised of 36 different genera belonging to three groupsviz., rotifera, cladocera and copepoda. There were 18 species of rotifers belonging to fifteen families and three orders. The arthropods comprised of 14 cladocerans and 4 copepods, of which the former belongs to seven families and the latter is belonging to two families Table 1. A total of 16 species were widely spread to all the study areas while some were limited in distribution. The limited species included Testudinella sp., Lepadella sp. and Macrothrix sp. found only in site 1; while Mytilinasp.,Hexarthrasp.,Rotariasp. and Daphnia sp. were found only in site 2, on the other handScaridiumsp.,Moinodaphniasp.,Simocephalussp.,Disperalonasp. andScapholeberissp. were found only in site 3.

Concomitant to above, the total number of zooplankton per site varied from 183 to 590 no. $/ \mathrm{ml}$. on the average, the total numbers of organism were recorded during the Post monsoon period which is applicable to all the sites. The rotifers were the most dominant in site $2(43.08 \%)$, the similar trend was observed in site 3 where the rotifers form the $38.60 \%$ of total abundance of the organism except in site 1 , where the cladocerans were the most abundant one $(46.35 \%)$.

The zooplankton species richness indices were generally higher in site 2 than site 1 and site 3, with Margalef index (R1) value is 3.04 shows in Table 2. This indicates that the site 2 were much richer in species than the other two water sources. The zooplankton population of site 2 and 3 were more diverse than the site 1with Simpson's diversity index $(\lambda)$ of 0.09 respectively. The number of abundant species (Hill's first diversity number) was also quite high in site 2 .

\section{CONCLUSIONS}

The analyzed differences in zooplankton composition, distribution patter and abundance in the investigated water bodies subjected to different biological factors by Davies et al., [10]. It has been observed that the species richness and diversity of zooplankton is affected by various environmental disruptions. The dominance of rotifers in two studied water reveals that the water became eutrophic; this is because the eutrophic water promote the growth of small sized zooplankton especially the rotifers [11]. During the post monsoon season, the water bodies were found to be richer qualitatively and quantitatively than the other seasons due to various reasons like the availability of abundant food, favorable temperature for the developmental stage. The objective of this investigation was therefore to develop our knowledge about the fact that the diversity, abundance of any water body sources is dependent upon various biological factors and 
the zooplankton are playing a vital role in the stability and integrity of aquatic ecosystem, but still indicated scarcity of information.

\section{REFERENCES}

1. R.S. Stemberger, "An inventory of rotifer species diversity of northern Michigan inland Lakes," ArchivfürHydrobiologie. vol. 118, pp. 283 -302, 1990.

2. S. K. Mukhopadhyay, B. Chattopadhyay, A. R. Goswami and A. Chatterjee, "Spatial variations in zooplankton diversity in waters contaminated with composite effluents," J. Limnol. vol. 66, pp. 97-106, 2007.

3. D. Rissik, D. Van Senden, M. Doherty, T. Ingleton, P. Ajani, L. Bowling, M. Gibbs, M. Gladstone M, T. Kobayashi, I. Suthers and W. Froneman, "Plankton-related environmental and water-quality issues," in Plankton, a guide to their ecology and monitoring for water quality, 1st ed. I.M.Suthers, D. Rissik, Eds. Melbourne: CSIRO Publishing, 2009, pp. 39-72. 4. Edmondson, W.T. (1959). Freshwater Biology 2nd Ed. John Wiley and Sons Inc., New York: $1-1248$.

5. Sharma, B.K. and Michael, R.G. (1987). Review of taxonomic studies on freshwater Cladocera from India with remarks on biogeography, Hydrobiologia. 145: 29-33.

6. Battish, S.K. (1992). Freshwater zooplankton of India. Oxford and IBH Publishing Co., New Delhi. 233.

7. Michael, R.G. and Sharma, B.K. (1998). Indian Cladocera (Crustacea: Branchiopoda: Cladocera) Fauna of India and Adjacent countries. Zoological Survey of India. 262.

.8. Sharma, B.K. (1998). Freshwater Rotifers (Rotifera: Eurotatoria). Fauna of West Bengal.State Fauna Series.3(11): 341-461.

9. Ludwig, J.A., Reynolds, J.F. (1988). Statistical Ecology: A Primer on Methods and Computing. John Wiley and Sons: New York.85-109.

10. Davies, O.A., Abowei, J. F. N., Otene, B.B. (2009). Seasonal abundance and distribution of plankton of Minichinda stream, Niger Delta, Nigeria. American Journal of Science Research, 2(2): 20-30.

11. Ovie, S.I., Adeniji, H.A. and Olowe, D.I. (1993). Isolation and growth of curve characteristics of a freshwater zooplankton for feeding early larvae and fry stages of fish. Journal of Aqua. Tropical, 8: 181-196.

Table 1: Abundance of Zooplankton Population in Three Study Areas

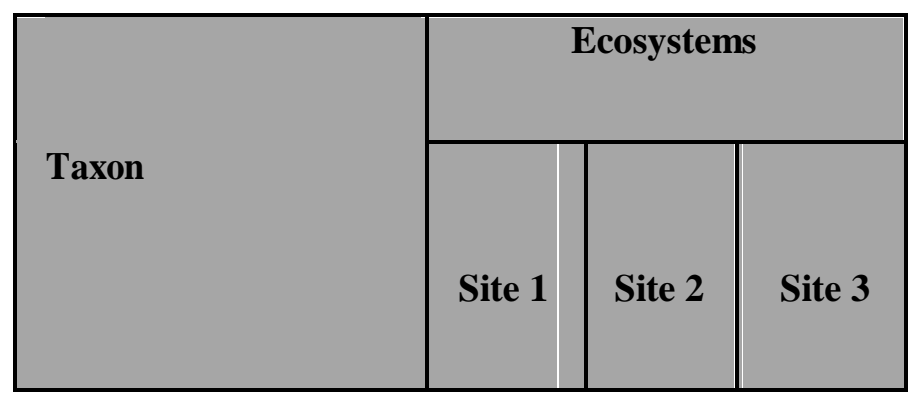


International Journal of Agriculture, Environment and Bioresearch

Vol. 5, No. 05; 2020

ISSN: $2456-8643$

\begin{tabular}{|l|c|c|c|}
\multicolumn{1}{|c|}{ Rotifera } & \multicolumn{2}{|c|}{} \\
\hline Brachionussp. & + & + & + \\
\hline Cephalodellasp. & + & + & - \\
\hline Mytilinasp. & & & \\
\hline Filiniasp. & - & + & - \\
\hline Asplanchnasp. & + & + & + \\
\hline Keratellasp. & + & + & + \\
\hline Lecanesp. & + & + & + \\
\hline Hexarthrasp. & - & + & - \\
\hline Trichocercasp. & + & + & + \\
\hline Anuraeopsissp. & + & + & - \\
\hline Testudinellasp. & + & - & - \\
\hline Horaellasp. & - & + & + \\
\hline Lepadellasp. & + & - & - \\
\hline Scaridiumsp. & + & + & + \\
\hline Rotariasp. & & & \\
\hline & & & \\
\hline
\end{tabular}


International Journal of Agriculture, Environment and Bioresearch

Vol. 5, No. 05; 2020

ISSN: $2456-8643$

\begin{tabular}{|l|c|c|c|} 
Sinantherinasp. & + & + & - \\
\hline Colurellasp. & + & + & - \\
& & &
\end{tabular}

\begin{tabular}{|c|c|c|c|}
\hline Cladocera & & & \\
\hline Bosminopsissp. & + & + & + \\
\hline Chydorussp. & + & + & - \\
\hline Macrothrixsp. & + & - & - \\
\hline Diaphanosomasp. & + & + & + \\
\hline Bosminasp. & + & + & + \\
\hline Moinodaphniasp. & - & - & + \\
\hline Moinasp. & - & + & + \\
\hline Ceriodaphniasp. & + & + & + \\
\hline Simocephalussp. & - & - & + \\
\hline Sidasp. & + & - & + \\
\hline Daphnia sp. & - & + & - \\
\hline Disperalonasp. & - & - & + \\
\hline Alonasp. & + & + & + \\
\hline Scapholeberissp. & - & - & + \\
\hline
\end{tabular}




\begin{tabular}{|l|c|c|c|}
\multicolumn{5}{|l|}{ Cladocera } & + & + & + \\
\hline Neodiaptomussp. & & & \\
\hline Mesocyclopssp. & + & + & + \\
\hline Heliodiaptomussp. & + & + & + \\
\hline Thermocyclopssp. & + & + & + \\
\hline
\end{tabular}

(Note: + denotes present and - denotes absent)

Table 2: Zooplankton Richness and Diversity of the Studied Water Bodies

\begin{tabular}{|c|c|c|c|}
\hline \multirow{2}{*}{ Index } & \multicolumn{3}{|c|}{ Ecosystems } \\
\cline { 2 - 4 } & & & \\
\cline { 2 - 4 } & Site 1 & Site 2 & Site 3 \\
\hline Margalef index $\left(\mathrm{R}_{1}\right)$ & & & 2.98 \\
\hline Simpson index $(\lambda)$ & 2.96 & 3.04 & 0.08 \\
\hline Hill's first Diversity Number $\left(\mathrm{N}_{1}\right)$ & 47.16 & 50.3 & 47.07 \\
\hline
\end{tabular}

